
\title{
$\angle S$ Research Suare \\ Buffalo Sperm Surface Proteome Profiling Reveals an Intricate Relationship Between Innate Immunity and Reproduction
}

\author{
Vipul Batra \\ National Dairy Research Institute \\ Vanya Bhushan \\ National Dairy Research Institute \\ Syed Ali \\ National Dairy Research Institute \\ Parul Sarwalia \\ National Dairy Research Institute \\ Subhash Solanki \\ National Dairy Research Institute \\ Arumugam Kumaresan \\ National Dairy Research Institute \\ Rakesh Kumar \\ National Dairy Research Institute \\ Tirtha Datta ( $\square$ tirthadatta@gmail.com ) \\ National Dairy Research Institute
}

\section{Research Article}

Keywords: Buffalo, sperm, beta-defensins, epididymis, glycosylation

Posted Date: January 15th, 2021

DOI: https://doi.org/10.21203/rs.3.rs-142480/v1

License: (c) (i) This work is licensed under a Creative Commons Attribution 4.0 International License. Read Full License 


\section{Abstract}

\section{Background}

Low conception rate (CR) despite insemination with morphologically normal spermatozoa is a common reproductive restraint which limits buffalo productivity. This accounts for a significant loss to the farmers and the dairy industry, especially in agriculture-based economies. The immune-related proteins on the sperm surface are known to regulate fertility by assisting the spermatozoa in their survival and performance in the female reproductive tract (FRT). Regardless of their importance, very few studies have specifically catalogued the buffalo sperm surface proteome. The study was designed to determine the identity of sperm surface proteins and to ascertain if the epididymal expressed beta-defensins (BDs), implicated in male fertility, are translated and applied onto buffalo sperm surface along with other immune-related proteins.

\section{Results}

The raw mass spectra data searched against in-house generated proteome database from UniProt using Comet search engine identified more than 300 proteins on the ejaculated buffalo sperm surface which were bound either by non-covalent (ionic) interactions or by a GPI-anchor. The singular enrichment analysis (SEA) revealed that most of these proteins were extracellular with varied binding activities and were involved in either immune or reproductive processes. Flow cytometry using six FITC-labelled lectins confirmed the prediction of glycosylation

of these proteins. Several beta-defensins (BDs), the anti-microbial peptides including the BuBD-129 and 126 were also identified amongst the buffalo sperm surface proteins. The presence of these proteins was confirmed by immunocytochemistry and IVF experiments.

\section{Conclusions}

The surface of the buffalo spermatozoa is heavily glycosylated because of the epididymal secreted glycoproteins like BDs and the GPI-anchored proteins. The glycosylation pattern, however, could be perturbed in the presence of elevated salt concentration or incubation with PI-PLC. The identification of numerous BuBDs on the sperm surface strengthens our hypothesis that these BDs assist the buffalo spermatozoa either in their survival or in performance in the FRT. Our results suggest that BuBD-129 is a sperm-surface BD which could have a role in buffalo sperm function. Further studies elucidating its exact physiological function are required to better understand its roles in the regulation of male fertility.

\section{Introduction}

The voyage of the spermatozoa in the female reproductive tract (FRT) entails surmounting of numerous impediments including the physical, thermal, chemical and immunological barriers. These include the vaginal acidic $\mathrm{pH}$, the mucus in the cervix, the leukocytes and anti-sperm antibodies of the immune system especially in the uterus, and the narrow utero-tubal junction in the oviduct $(1,2 ; 3,4$ and 5$)$. To overcome these obstructions the spermatozoa must acquire surface properties primarily customized for this strenuous voyage. The process of sperm surface remodelling (SSR), which occurs during the epididymal transit of the spermatozoa tailors the sperm surface which assists them in survival and fertilization in the FRT $(6,7$, and 8$)$. The biomolecular constitution of the mammalian testicular spermatozoa changes continuously and progressively in the luminal fluid of the various epididymal regions due to the secretory and re-absorptive actions of the epithelial cells that 
line this organ $(9,10,11$ and 12). The remodelling events include a) enzymatic cleavage of the membraneassociated proteins $b$ ) variations in the composition of membrane-lipids $c$ ) re-organization of the glycoconjugates (GCs) associated with the sperm glycocalyx d) removal or addition of (glyco)proteins $(9,13$, and 14). A blend of distinct secretagogues is known to be added onto the sperm-surface in these three epididymal regions viz. caput, corpus and cauda. A majority of these secretagogues include the immune-related (glyco)proteins often implicated in sperm survival and fertility. The epididymal secreted proteins involved in sperm maturation could be adhered on their sperm plasma membrane either by low binding affinity or they could be transmembrane. Many of these components bind transiently, for example, molecules acquired in the distal epididymal regions which are obligatory for traversing the array of mucosal fluids and extracellular matrices in the FRT $(15,16)$. The adhered proteins in the peripheral sperm environment bind the sperm-surface most likely by the electrostatic/hydrophobic interactions. These proteins change the sperm-surface characteristics as they interact with the transiting spermatozoa. The epididymal secretome usually involves the binding of hydrophobic proteins, the glycans-modifying enzymes such as glycosidases and glycosyltransferases (17, 18 and 19), proteases and protease inhibitors (20), proteins involved in immunological protection (3) and the ones that protect the sperm from oxidative injuries (21). Besides, many membranous vesicles rich in cholesterol, sphingolipids and $\mathrm{Ca}^{+2}$ known as epididymosomes exist in the epididymal lumen. These extracellular vesicles mainly carry the GPI linked proteins, many of which are inserted in the sperm plasma membrane $(22,23$ and 24$)$. As mentioned earlier, many of the added (glyco) proteins on sperm-surface belong to defence family and their glycosylation patterns are critical for either stabilizing the sperm-membrane during the immune attack by immune cells or assisting in immune-evasion in the $\operatorname{FRT}(25,26,27$ and 28$)$. The rendering of a highly glycosylated surface coat on the spermatozoa after epididymal transit, not only acts as a barrier between the spermatozoa and female immune system, but also assists in them in cervical mucus penetration (CMP), oviductal epithelial cell (OEC) binding, identification of the zona pellucida and oolemma, and juxtaposition of the sperm and the oocyte plasma membrane $(3,19,29,30$ and 31). The sperm-surface proteins and their associated glycans also play a key role in the acquisition of motility and fertilizing ability in the epididymis, their protection, selection and secondary maturation in the FRT (19 and 32).

The buffalo was considered as a model for this study due to its economic importance in the agriculture-based economies. It has been reported that more people depend on buffalo than on any other domestic animal (33). Although it is a premier dairy animal with superior milk-producing ability, idiopathic male infertility is a common reproductive limitation in buffalo. A sizeable number of high genetic merit bull calves originally selected for Al programs are discarded because their semen ends up yielding dismal conception rates (CRs) between 30 to $50 \%$, reflecting poor fertilizing ability $(34,35$ and 36$)$. The factors that contribute to male fertility are relatively poorly understood, especially in bovine species (37). The prediction of fertility assessment currently relies on analyses of sperm functional parameters apart from the physical examination of the bulls, nonetheless, the correlation between these parameters and CR are often inconsistent (38). Therefore, a better understanding of the novel factors which regulate fertility e.g. sperm-surface proteins is required to gain insights into the factors behind idiopathic male infertility.

The objective of this study was the identification and in silico characterization of the post-testicular maturation antigens and peripheral proteins that interact with the buffalo sperm plasma membrane either through noncovalent (ionic) interactions or through a GPI-anchor. We also sought to determine the existence of the 
epididymal expressed BDs on buffalo spermatozoa and to predict their reproductive functional significance through immunofluorescence and in vitro fertilization experiments.

\section{Results}

Only the ejaculates that were milky or creamy in colour, homogenous in consistency i.e. free from flakes/clumps with a minimum sperm concentration of $600 \times 10^{6} / \mathrm{ml}$ were considered for swim-up and further downstream experiments. The average motility and viability of seven representative sample ejaculates after processing was $81.84 \pm 1.20$ and $85.85 \pm 1.16$ respectively. The samples were diluted according to the experiments, as mentioned, wherever required.

\section{Hundreds of proteins are bound on buffalo sperm surface either through electrostatic interactions or by a GPI anchor}

The extracted sperm-surface proteins indicated enough diversity among the types of protein removed using the seven treatment groups viz. $2 \mathrm{X}-30,2 \mathrm{X}-60,4 \mathrm{X}-30,4 \mathrm{X}-60$, and $1 \mathrm{U} / \mathrm{mL}, 1.5 \mathrm{U} / \mathrm{mL}$ and $2 \mathrm{U} / \mathrm{mL}$ representing the elevated salt extractions (2X/4X-DPBS for 30/60 min) and PI-PLC extractions, respectively (Supplementary Figs. 1 and 2). All the elevated salt and PI-PLC treatments' extracted sperm-surface proteins produced $>20000$ PEP-XML spectra. The iprophet tool correctly identified more than 300 proteins in all of the treatments at $p>=$ 0.99 where $p$ indicates the probability that the spectra have been correctly matched to its analogous peptide (Table 1). A total of $317,391,395$ and 432 proteins were identified in $2 X-30,4 X-30,2 X-60$ and $4 X-60$ (DPBS) treatments respectively. On the other hand, 385,353 and 364 proteins were identified in the $1 \mathrm{U}, 1.5 \mathrm{U}$ and $2 \mathrm{U} / \mathrm{mL}$ PI-PLC treatments, respectively. At $p \geq 0.99$ zero proteins were found to be incorrectly identified. Many proteins were found to be unique to each sub-group of either treatment (elevated salt or PI-PLC) demonstrating that the individual combinations of incubation time and salt/enzyme concentration exerted disparate effects on

disrupting the non-covalent/GPI interactions among the proteins of sperm surface. Moreover, nearly $30 \%$ of the proteins were observed as common between any two treatment subgroups (Supplementary Figs. 1 and 2). 
Table 1

Treatments for sperm-surface protein extraction and corresponding TPP results indicating total spectra, correctly and incorrectly identified proteins at $\mathrm{p} \geq 0.6$ and 0.99

\begin{tabular}{|c|c|c|c|c|c|c|c|}
\hline Sample & $\begin{array}{l}\text { PEP- } \\
\text { XML } \\
\text { Total } \\
\text { spectra }\end{array}$ & $\begin{array}{l}\text { Ipro.pep.xml } \\
\text { Total } \\
\text { spectra }\end{array}$ & $\begin{array}{l}\text { Prot.xml } \\
\text { Total } \\
\text { proteins }\end{array}$ & $\begin{array}{l}\text { Total } \\
\text { proteins } \\
\text { with p } \\
\geq 0.6\end{array}$ & $\begin{array}{l}\text { Incorrectly } \\
\text { identified with } \\
\text { iprophet } p \geq \\
0.6\end{array}$ & $\begin{array}{l}\text { Total } \\
\text { proteins } \\
\text { with } \mathrm{p} \geq \\
0.99\end{array}$ & $\begin{array}{l}\text { Incorrectly } \\
\text { identified with } \\
\text { iprophet } p \geq \\
0.99\end{array}$ \\
\hline $\begin{array}{l}2 X- \\
\text { DPBS- } \\
30 \text { min }\end{array}$ & 26535 & 7252 & 1733 & 875 & 76 & 317 & 0 \\
\hline $\begin{array}{l}4 X- \\
\text { DPBS- } \\
30 \mathrm{~min}\end{array}$ & 26470 & 8399 & 1725 & 956 & 76 & 391 & 0 \\
\hline $\begin{array}{l}2 X- \\
\text { DPBS- } \\
60 \mathrm{~min}\end{array}$ & 25947 & 7742 & 1898 & 1013 & 90 & 395 & 0 \\
\hline $\begin{array}{l}4 X- \\
\text { DPBS- } \\
60 \mathrm{~min}\end{array}$ & 25951 & 8210 & 2162 & 1244 & 99 & 432 & 0 \\
\hline $1 \mathrm{U} / \mathrm{ml}$ & 24829 & 6557 & 1788 & 992 & 99 & 385 & 0 \\
\hline $1.5 \mathrm{U} / \mathrm{ml}$ & 24587 & 6343 & 1932 & 1005 & 76 & 353 & 0 \\
\hline $2 \mathrm{U} / \mathrm{ml}$ & 24881 & 5978 & 1662 & 793 & 63 & 364 & 0 \\
\hline
\end{tabular}

Overall, we report a total of 352 buffalo sperm-surface proteins that were identified in the protein fractions extracted from sperm incubation with elevated salt (2X/4XDPBS) or enzyme (PI-PLC) concentration. The LCMS/MS data analysis identified several BDs including the two Class-A beta-defensins (CA-BDs) viz. BD-129 and 126 amongst the other -surface proteins Notwithstanding, only 119 proteins were common among the elevated salt and PI-PLC treatments which were predicted to be extracellular (Supplementary Fig. 2 and Supplementary sheet-Results). A remarkable diversity in the range of M.W and pl was observed among the selected spermsurface proteins (Supplementary sheet-Results). The BDs were found to be among the proteins with lowest molecular weight while the angiotensin-converting enzyme (ACE) and the two uncharacterized proteins (UniProt ID: F1MD73 and F1MQ37) were the on the other end of the scale ( $M_{r}=141.24,190.10$ and 227.10 respectively). The BDs Spag-11D and BD-129 had the highest pl while the Acrosin inhibitor 1 had the lowest pl (4.25). Only three (5\%) proteins viz. Sperm acrosome membrane-associated protein1, Angiotensin-converting enzyme and an uncharacterized protein (F1MD73) were predicted to contain a transmembrane segment. A high level of PTMs, especially glycosylation appears to modify the analyzed proteins. More than $80 \%$ of the analyzed proteins were predicted to possess at least either one $\mathrm{N}$-glycosylation site or one 0-glycosylation site. The uncharacterized protein F1MQ37 and Keratin contained a maximum of 47 and 52 0-glycosylation sites. The BD-126 and 134 were predicted to contain one N-glycosylation site while the BD-129 was predicted to contain three N-glycosylation sites. BD-126 was predicted to contain two 0-glycosylation sites whereas the BD-129 predicted to contain eight such sites (Supplementary sheet-Results).

\section{Proteins involved in the immune response and reproductive processes adorn the buffalo sperm surface}


GO analysis was performed on the identified 119 extracellular (EC) sperm-surface proteins (Supplementary Fig. 2) wherein the annotation terms for Biological Process, Molecular Function and Cellular Component were determined. The 119 buffalo sperm-surface proteins were successfully mapped to 63 entries in the background dataset. The singular enrichment analysis (SEA) for Biological Process terms' identified reproductive processes, sexual reproduction, immune response and response to biotic/abiotic stimulus terms as the major GO annotations (Table 2) in the input list vis-à-vis the background reference dataset, the Bovine genome locus (Bovine Genome Database): GLEAN_03528. The scatter plot analysis (SPA) using SimRel for Biological Process similarly indicated semantic similarities between reproductive process functions, immune response and response to biotic/abiotic stimulus terms (Fig. 1) as observed by their closeness in the displayed two-dimensional space. The SEA for Molecular Function indicated that the majority of proteins were (Fig. 1) involved in catalytic and binding (carbohydrate or protein) functions. The SPA for Molecular Function (Fig. 1) also identified protein binding and catalytic activity as the major GO terms with the highest uniqueness index values and the least dispensability scores. Most of the proteins were found to be extracellular, vesicular or part of the plasma membrane as indicated by the SEA and SPA for the Cellular Component terms (Table 2 and Supplementary sheetResults). The low p-values from the Fisher's test and the results of Yekutieli test (low FDRs) are indicative of high confidence in the determined annotation terms for the input list in the SEA (Table 2). Similarly, the $\operatorname{lower}_{\log } \log _{10}$ values and dispensability score with high uniqueness index indicate the reliability of the GO annotation terms for the input list in the SPA (Supplementary sheet-Results). Overall, the results suggest that the buffalo sperm surface is adorned with vesicular or extracellular proteins which are involved in reproduction specific activities, immune responses, responses to biotic/abiotic stimuli and perform catalytic or carbohydrate/protein binding functions.

\section{Cytometry reveals removal of glycosylated proteins from buffalo sperm surface after elevated salt/PI-PLC treatment}

The Flow cytometry analyses were performed on the control sample (NCM), spermatozoa incubated in elevated salt for $30 \mathrm{~min}$ (2X-DPBS) and spermatozoa incubated with $2 \mathrm{U} / \mathrm{mL}$ PI-PLC to assess the corresponding changes in glycosylation after either treatment. The analyses revealed a reduction in O-linked, as well as $\mathrm{N}$-linked glycans after elevated salt and PI-PLC treatments as illustrated by the decline in the MFI, produced upon binding of FITCbound lectins on the buffalo sperm-surface (Fig. 2). A panel of five O-linked glycans specific lectins viz. ABL, JAC, MAL-II, LCA and PNA and one N-linked glycan specific lectin, LEL was used. The Brown-Forsythe test for all the lectins was found to produce a non-significant $p$-value indicating no differences in standard deviations of the MFIs produced in these groups $(p<0.05)$. The unstained spermatozoa were excluded from the analysis by gating and the singlets were chosen and the analyses were performed on single, stained spermatozoa. The O-linked glycan-binding lectin ABL has specificity towards Thomsen-Friedenreich antigen, galactosyl $(\beta-1,3) \mathrm{N}$ acetylgalactosamine (39). It produced a mean fluorescence intensity (MFI) of 1, 56,610.0 in the control sample which differed significantly $(\mathrm{p}<0.001)$ from the MFI produced in the spermatozoa incubated in $2 X-D P B S(1$, 25,032.0) or treated with PI-PLC $(1,29,399.0)$ as assessed by one-way ANOVA (Fig. 2 and Supplementary Fig. 3). The lectin JAC which has a sugar specificity towards galactose of O-linked glycans preferring the structure galactosyl $(\beta-1,3) \mathrm{N}$-acetylgalactosamine also produced higher MFI in the control sample $(2,47,848.0)$ in comparison to either the $2 X-30$ sample $(1,71,757.0)$ or the PI-PLC treated sample $(1,27,951.0)$. The post-hoc analysis indicated that the reduction in MFI for JAC after either the salt treatment $(p<0.001)$ or the PI-PLC 
treatment $(p<0.0001)$ was not only significantly different from the control sample but also each other $(p<0.01)$ (Fig. 2 and Supplementary Fig. 3). The N-linked glycan-binding lectin LEL which is specific for [GlcNAc] 1-3, Nacetylglucosamine is also removed from the sperm surface on exposing the spermatozoa to elevated salt milieu producing a diminished MFI of 48,715.0 which didn't differ significantly from the MFI produced in control samples (92,968.0). (Fig. 2 and Supplementary Fig. 3). The exposure of PI-PLC, nonetheless, reduced the MFI fluorescence significantly to $32,161.0(p<0.05)$. The LCA lectin specific for mannose and glucose produced significantly $(p<0.001)$ reduced MFI of $26,979.0$ in the elevated salt-treated spermatozoa when compared to the control sample (36559.0) (Fig. 2 and Supplementary Fig. 3). Conversely, the MFI increased minutely to 38,451.0 after exposure to PI-PLC. The $a-2,3$ linked sialic acid-binding lectin MAL-II $(p<0.001)$ similarly produced a significantly higher MFI in the control sample (6015.0) in comparison to the 2X-30 sample (4820.0) (Fig. 2 and Supplementary Fig. 3). Nevertheless, as observed for LCA binding, an MFI increased albeit significant $(p<0.001)$ after PI-PLC treatment (7435.0). The MFI produced upon MAL-II binding differed significantly $(p<0.0001)$ from each other (Fig. 2 and Supplementary Fig. 3). The acrosomal intactness indicator lectin PNA, which binds the asialylated galactosyl $(\beta-1,3) \mathrm{N}$-acetylgalactosamine produced higher MFI in both the salt-treated $(28,334.0)$ and the PI-PLC exposed spermatozoa $(23,075.0)$ when compared to the control spermatozoa $(18,759.0)$. However, the rise was statistically insignificant for both the treatments (Fig. 2 and Supplementary Fig. 3).

Overall, both the treatments reduced the availability of respective cognate glycans for most lectins except the PNA after salt treatment. Contrarily, the PI-PLC treatment led to increased exposure of $a-2,3$ linked sialic acid and asialylated galactosyl $(\beta-1,3) \mathrm{N}$-acetylgalactosamine. Furthermore, both the treatments were significantly different from each other vis-à-vis the MFI produced upon lectin binding on the surface of the buffalo spermatozoa. 
Table 2

The major GO terms, Fisher's p-values and Yekutieli result for Multi-test alignments (FDR under dependency) for SINGULAR ENRICHMENT ANALYSIS SEA of Biological Process, Molecular Function and Cellular Component for the sperm-surface proteins in the input list.

\begin{tabular}{|c|c|c|c|c|c|c|c|c|}
\hline \multicolumn{3}{|c|}{ Biological Process } & \multicolumn{3}{|c|}{ Molecular Function } & \multicolumn{3}{|c|}{ Cellular Component } \\
\hline Term & $\begin{array}{l}\mathrm{p}- \\
\text { value }\end{array}$ & FDR & Term & p-value & FDR & Term & $\begin{array}{l}\mathrm{p}- \\
\text { value }\end{array}$ & FDR \\
\hline $\begin{array}{l}\text { Multicellular } \\
\text { organismal } \\
\text { process }\end{array}$ & $\begin{array}{l}2.00 \mathrm{E}- \\
27\end{array}$ & $\begin{array}{l}1.40 \mathrm{E}- \\
24\end{array}$ & $\begin{array}{l}\text { Enzyme } \\
\text { binding }\end{array}$ & $\begin{array}{l}2.90 \mathrm{E}- \\
24\end{array}$ & $\begin{array}{l}2.90 \mathrm{E}- \\
22\end{array}$ & $\begin{array}{l}\text { Membrane- } \\
\text { bounded } \\
\text { vesicle }\end{array}$ & $\begin{array}{l}5.70 \mathrm{E}- \\
85\end{array}$ & $\begin{array}{l}6.10 \mathrm{E}- \\
83\end{array}$ \\
\hline $\begin{array}{l}\text { Sexual } \\
\text { reproduction }\end{array}$ & $\begin{array}{l}1.90 \mathrm{E}- \\
25\end{array}$ & $\begin{array}{l}6.60 \mathrm{E}- \\
23\end{array}$ & $\begin{array}{l}\text { Ubiquitin } \\
\text { protein ligase } \\
\text { binding }\end{array}$ & $\begin{array}{l}8.20 \mathrm{E}- \\
16\end{array}$ & $\begin{array}{l}4.10 \mathrm{E}- \\
14\end{array}$ & Vesicle & $\begin{array}{l}5.70 \mathrm{E}- \\
85\end{array}$ & $\begin{array}{l}6.10 \mathrm{E}- \\
83\end{array}$ \\
\hline Reproduction & $\begin{array}{l}1.30 \mathrm{E}- \\
24\end{array}$ & $\begin{array}{l}3.00 \mathrm{E}- \\
22\end{array}$ & $\begin{array}{l}\text { Protein } \\
\text { binding }\end{array}$ & $\begin{array}{l}6.00 \mathrm{E}- \\
11\end{array}$ & $\begin{array}{l}2.00 \mathrm{E}- \\
09\end{array}$ & $\begin{array}{l}\text { Extracellular } \\
\text { region part }\end{array}$ & $\begin{array}{l}3.80 \mathrm{E}- \\
70\end{array}$ & $\begin{array}{l}2.70 \mathrm{E}- \\
68\end{array}$ \\
\hline $\begin{array}{l}\text { Reproductive } \\
\text { process }\end{array}$ & $\begin{array}{l}1.20 \mathrm{E}- \\
22\end{array}$ & $\begin{array}{l}2.10 \mathrm{E}- \\
20\end{array}$ & $\begin{array}{l}\text { Unfolded } \\
\text { protein } \\
\text { binding }\end{array}$ & $\begin{array}{l}3.60 \mathrm{E}- \\
09\end{array}$ & $\begin{array}{l}9.00 \mathrm{E}- \\
08\end{array}$ & $\begin{array}{l}\text { Extracellular } \\
\text { region }\end{array}$ & $\begin{array}{l}3.60 \mathrm{E}- \\
62\end{array}$ & $\begin{array}{l}1.90 \mathrm{E}- \\
60\end{array}$ \\
\hline $\begin{array}{l}\text { Positive } \\
\text { regulation of } \\
\text { biological } \\
\text { process }\end{array}$ & $\begin{array}{l}1.90 \mathrm{E}- \\
21\end{array}$ & $\begin{array}{l}2.70 \mathrm{E}- \\
19\end{array}$ & $\begin{array}{l}\text { Protein } \\
\text { domain } \\
\text { specific } \\
\text { binding }\end{array}$ & $\begin{array}{l}1.80 \mathrm{E}- \\
08\end{array}$ & $\begin{array}{l}3.50 \mathrm{E}- \\
07\end{array}$ & Cytoplasm & $\begin{array}{l}3.90 \mathrm{E}- \\
32\end{array}$ & $\begin{array}{l}1.60 \mathrm{E}- \\
30\end{array}$ \\
\hline $\begin{array}{l}\text { Anatomical } \\
\text { structure } \\
\text { development }\end{array}$ & $\begin{array}{l}4.70 \mathrm{E}- \\
21\end{array}$ & $\begin{array}{l}5.50 \mathrm{E}- \\
19\end{array}$ & $\begin{array}{l}\text { Carbohydrate } \\
\text { binding }\end{array}$ & $\begin{array}{l}8.40 \mathrm{E}- \\
06\end{array}$ & 0.00014 & $\begin{array}{l}\text { Membrane- } \\
\text { bounded } \\
\text { organelle }\end{array}$ & $\begin{array}{l}1.60 \mathrm{E}- \\
29\end{array}$ & $\begin{array}{l}5.70 \mathrm{E}- \\
28\end{array}$ \\
\hline $\begin{array}{l}\text { Regulation of } \\
\text { biological } \\
\text { quality }\end{array}$ & $\begin{array}{l}4.20 \mathrm{E}- \\
18\end{array}$ & $\begin{array}{l}4.20 \mathrm{E}- \\
16\end{array}$ & Binding & 0.00037 & 0.0037 & $\begin{array}{l}\text { Extracellular } \\
\text { space }\end{array}$ & $\begin{array}{l}9.30 \mathrm{E}- \\
25\end{array}$ & $\begin{array}{l}2.20 \mathrm{E}- \\
23\end{array}$ \\
\hline $\begin{array}{l}\text { Positive } \\
\text { regulation of } \\
\text { cellular } \\
\text { process }\end{array}$ & $\begin{array}{l}5.30 \mathrm{E}- \\
18\end{array}$ & $\begin{array}{l}4.70 \mathrm{E}- \\
16\end{array}$ & $\begin{array}{l}\text { Nucleotide } \\
\text { binding }\end{array}$ & 0.00041 & 0.0037 & Organelle & $\begin{array}{l}1.60 \mathrm{E}- \\
23\end{array}$ & $\begin{array}{l}3.50 \mathrm{E}- \\
22\end{array}$ \\
\hline $\begin{array}{l}\text { System } \\
\text { development }\end{array}$ & $\begin{array}{l}1.10 \mathrm{E}- \\
17\end{array}$ & $\begin{array}{l}8.90 \mathrm{E}- \\
16\end{array}$ & $\begin{array}{l}\text { Enzyme } \\
\text { regulator } \\
\text { activity }\end{array}$ & 0.00041 & 0.0037 & $\begin{array}{l}\text { Intracellular } \\
\text { part }\end{array}$ & $\begin{array}{l}8.60 \mathrm{E}- \\
20\end{array}$ & $\begin{array}{l}1.70 \mathrm{E}- \\
18\end{array}$ \\
\hline $\begin{array}{l}\text { Response to } \\
\text { stimulus }\end{array}$ & $\begin{array}{l}5.10 \mathrm{E}- \\
17\end{array}$ & $\begin{array}{l}3.60 \mathrm{E}- \\
15\end{array}$ & $\begin{array}{l}\text { Catalytic } \\
\text { activity }\end{array}$ & 0.0022 & 0.012 & $\begin{array}{l}\text { Plasma } \\
\text { membrane }\end{array}$ & $\begin{array}{l}7.80 \mathrm{E}- \\
18\end{array}$ & $\begin{array}{l}1.30 \mathrm{E}- \\
16\end{array}$ \\
\hline $\begin{array}{l}\text { Cellular } \\
\text { developmental } \\
\text { process }\end{array}$ & $\begin{array}{l}1.10 \mathrm{E}- \\
16\end{array}$ & $\begin{array}{l}7.00 \mathrm{E}- \\
15\end{array}$ & $\begin{array}{l}\text { Receptor } \\
\text { binding }\end{array}$ & 0.0024 & 0.012 & $\begin{array}{l}\text { Cytoplasmic } \\
\text { membrane- } \\
\text { bounded } \\
\text { vesicle }\end{array}$ & $\begin{array}{l}4.80 \mathrm{E}- \\
15\end{array}$ & $\begin{array}{l}6.10 \mathrm{E}- \\
14\end{array}$ \\
\hline \multirow[t]{2}{*}{$\begin{array}{l}\text { Response to } \\
\text { biotic stimulus }\end{array}$} & $\begin{array}{l}1.90 \mathrm{E}- \\
13\end{array}$ & $\begin{array}{l}5.60 \mathrm{E}- \\
12\end{array}$ & & & & $\begin{array}{l}\text { Plasma } \\
\text { membrane } \\
\text { part }\end{array}$ & $\begin{array}{l}5.00 \mathrm{E}- \\
09\end{array}$ & $\begin{array}{l}3.90 \mathrm{E}- \\
08\end{array}$ \\
\hline & & & & & & Cell part & $\begin{array}{l}4.80 \mathrm{E}- \\
06\end{array}$ & $\begin{array}{l}2.60 \mathrm{E}- \\
05\end{array}$ \\
\hline
\end{tabular}




\section{Differential spatial distribution of BuBD-129 and 126}

The peptides GRCKEYCNMDEKELDK for BuBD-129 and NKTGNCRSTCRNGEK for BuBD-126 were predicted to be highly antigenic and were thus adjudged as the best B-cell epitopes. This is because they were predicted to be preferentially present in turns and loops and had a comparatively higher probability for being found on the surface (Supplementary Fig. 4). Initially, the crude concentration of the isolated lgGs assayed by measuring the $\mathrm{A}_{280}$ was $155049 \mathrm{ng} / \mu \mathrm{l}$ and $168722 \mathrm{ng} / \mu \mathrm{l}$ for the CA-BDs, BuBD-129 and 126 respectively (Supplementary Fig. 5). Subsequently, Bradford's assay was used to ascertain the more accurately and a concentration of $0.5 \mathrm{ug} / \mathrm{ml}$ was fixed for further experiments like the IF, IVF studies.

The immunocytochemistry (ICC) studies, anti-BuBD-129 and 126 antibodies revealed that the two CA-BDs, BuBD129 and 126 localized differentially on the surface of the buffalo bull spermatozoa (Fig. 3). Thus, a variation in the spatial distribution pattern was observed in the two class-A BuBDs (CA-BDs) wherein the BuBD-129 was present along the periphery of the spermatozoa, like the primate DEFB-126. The BuBD-126, however, was found to be present preferentially on the acrosomal and post-acrosomal and in the tail region while being absent in the mid-piece region (Fig. 3). The fluorescence produced by the BuBD-129 and 126 diminished when the spermatozoa were incubated in an elevated salt environment. The spermatozoa incubated in 2X-DPBS for 30 min appear to lose the sperm-surface bound BuBD-126 uniformly from the sperm surface, nonetheless, the spermsurface bound BuBD-129 retained on the post acrosomal region although it was lost from the mid-piece and the tail region of the buffalo bull spermatozoa (Fig. 3). A thin band at the acrosomal-region fluoresced despite the loss of fluorescence signal from the remaining regions of the spermatozoa. The effect for the PI-PLC treatment, however, was markedly different for the sperm surface-bound BuBD-129. The spermatozoa exposed to $2 \mathrm{U}$ of PIPLC lost the fluorescence signal for BuBD-129 from the entire spermatozoa. Nevertheless, the fluorescence pattern for BuBD-126 was similar to what was observed in 2X-DPBS treatment albeit weaker in intensity indicating partial loss of the bound BuBD-126 (Fig. 3).

\section{Blocking BuBD-129 on sperm surface hinders cleavage, Morula and Blastocyst formation rates}

The addition of anti-BuBD-129 antibody in the fertilization medium appeared to hamper the fertilization in a dosedependent manner (Fig. 4). The percentage of cleaved oocytes decreased in the 1:15000 dilution group compared to the control group which further dropped significantly $(P<0.05)$ in the 1:10000 and 1:5000 $(P<0.00001)$ dilution. Both the 1:10000 and 1:15000 differed significantly $(p<0.001)$ from the 1:5000 dilution and the control group for the number of cleaved oocytes. The subsequent stages of embryo development e.g. the morula formation also exhibited a similar trend. The percentage of morula formed decreased in the 1:15000 dilution but declined significantly $(P<0.05)$ in 1:10000 dilution which further reduced $(P<0.00001)$ in the 1:5000 dilution group. As expected, the blastocyst formation rate was highest in control which declined $(p<0.01)$ on the addition 
of anti-BuBD-129 in 1:15000 and 1:10000 dilution groups (Fig. 4). No blastocyst was formed in the 1:5000 dilution group.

\section{Discussion}

The present study was designed to identify the proteins associated with peripheral coats on the buffalo spermatozoa acquired during their transit through the epididymis and other ducts before ejaculation. The overrepresented immune-related glycoproteins/glycoconjugates of sperm surface are known to regulate male fertility e.g. by assisting in immune-evasion (28 and 29). We sought to specifically remove i) the proteins bound through electrostatic interactions (by elevated $\mathrm{NaCl}$ ) ii) the $\mathrm{GPI}$-anchored proteins (by PI-PLC). We also wanted to determine if the previously detected epididymal transcripts of buffalo beta-defensins (BDs) are translated and their gene products are subsequently applied to the buffalo sperm surface. Shotgun proteomic profiling revealed that the majority of the extracellular proteins is involved in immune response or reproductive processes (Table 2). Eight BDs including two BDs, implicated in male fertility viz. the heavily 0-glycosylated BuBD-129 and BuBD-126 were also identified along with other sperm-surface proteins (Supplementary sheet-Results). The in silico prediction of glycosylation of sperm surface was validated by flow cytometry using six lectins (Fig. 2). The presence of BuBD-129 and 126 was confirmed by immunofluorescence which revealed a differential immunolocalization pattern of these BDs (Fig. 3). Besides, the blocking of BuBD-129 with antibodies was found to hamper the fertilization of buffalo oocytes which subsequently affected embryogenesis (Fig. 4).

The sperm surface plays a crucial role in biomolecular interactions, intracellular communication and gamete recognition. However, the testicular spermatozoa still require distinct post-gonadal modifications to become competent to traverse the FRT and fertilize the oocyte (19 and 40). The concluding stages of the sperm differentiation, including the tailoring of its surface, occur outside the gonads and do not appear to be regulated or mediated by the germline genome. Therefore, subtle interactions between the sperm and the luminal milieu of the epididymis modify the surface of spermatozoa in a series of sequential biochemical modifications which includes removal or addition of (glyco)proteins and changes in the glycoconjugates (GCs) associated with these proteins $(9,13,19$ and 41). Broadly, two distinctive and separate populations of (glyco)proteins have been described on mammalian spermatozoa which are differentiated based on their interactions with sperm-surface. One of them is adsorbed onto the sperm surface by either electrostatic or hydrophobic interactions and isn't integrated into the sperm plasma membrane $(3,19,42$ and 43$)$. To elucidate such a sperm surface antigen, we sought to remove the non-covalently linked epididymal proteins from the buffalo spermatozoa surface using an elevated $\mathrm{NaCl}$ concentration (DPBS treatment). It had been documented more than a decade ago that a population of non-covalently bound sperm surface (glyco)proteins could be released by exposing the macaque spermatozoa to 2X DPBS (300 mM) (44). The LC-MS/MS data analysis identified more than 300 salt extracted proteins representing the electrostatic proteome of buffalo sperm surface. Our results revealed that several BDs along with a multitude of immune response-related (glyco)proteins are applied on the buffalo sperm surface presumably during their epididymal transit wherein a myriad of such physiologically relevant critical alterations $\operatorname{occur}(45,46,47$ and 48). Many (glyco)proteins are known to be released from the surface of mammalian spermatozoa post elevated salt extractions including cattle PDC-109 and primate DEFB-126 which play diverse roles ranging from epithelial cell binding to immune defense $(49,50$ and 51$)$. The other population of spermsurface proteins is GPI-linked and is known to be firmly integrated into particular microdomains on its plasma membrane. Most of the GPI-linked proteins are laid down on the sperm-surface during epididymal transit of the sperm and these (glyco) proteins have aptly been addressed as 'maturation antigens (48, 52, 53 and 54). We also 
removed the GPI-linked proteins from buffalo sperm-surface using the enzyme PI-PLC and included them in the subsequent $\mathrm{GO}$ and singular enrichment analysis.

Throughout nature, innate immunity and sexual reproduction are tightly linked. Our results also indicated that majorly the proteins involved in the immune response and reproductive processes adorn the buffalo sperm surface. A growing body of evidence suggests that a major fraction of sperm-surface proteins belong to immune defence family and are required for the surmounting the immunologic impediments encountered by the spermatozoa in the FRT $(3,48,55,56,57,58$ and 59). Thus, an intimate and intricate relationship exists between the innate immune responses and reproductive processes varying from follicle development, gestation, and sperm cell selection to development of tolerance towards the sperm and the conceptus (60). Accordingly, the epididymis-specialized genes are known to be overrepresented by the genes encoding secretory proteins involved in the innate immune response, as observed in this study $(16,56,61,62$ and 63$)$. Many molecules have been discovered in the lumen of the mammalian epididymis that help the spermatozoa during their stay in the male reproductive tract (MRT) and their voyage throughout the FRT e.g. the highly glycosylated and negatively charged, antimicrobial peptides, beta-defensins (BDs) $(64,65$ and 66). We identified eight BDs including the two CA-BDs viz. BuBD-129 and 126 on the buffalo sperm-surface. This indicated that these genes (CA-BDs) are not only expressed and translated successfully in the epididymis but also are applied as peripheral coats onto the buffalo sperm surface. Recently, there has been a surge in reports that link the BDs with the regulation of male fertility, in several mammalian species $(38,45,51,67,68,69$ and 70$)$. Interestingly, the number of BD genes, thus the epididymal secreted BDs found on sperm, are highly variable in different species at least partly, due to the differences in microbial load, historical contingency, genetic drift and disparate ecological niches occupied (64, 71 and 72) The eight epididymal BDs found on buffalo sperm surface are among the class of proteins that are weakly bound. Many BDs are known to be expressed and secreted in the epididymal epithelium cells which subsequently interact with the traversing spermatozoa surface $(43,51,66,73$, and 74$)$. The reasons for the BDs to be amongst the dominant molecules of the buffalo sperm surface could be their ability to interact with phospholipid membranes and their immunologic activity.

The flow cytometry not only validated the presence of the cognate glycans for the six lectins but also demonstrated by a reduction in O-linked as well as N-linked glycans after elevated salt and PI-PLC treatments. Both the treatments led to a decline in the MFI upon lectin binding on buffalo sperm-surface thus correlating the loss of glycoconjugates linked to the glycoproteins. The glycocalyx of the sperm is the molecular frontier which is directly in contact with the hostile and immunologic milieu of the FRT. We have shown that the BuBD-129 is an atypical BD, possessing a long $C^{\prime}$ tail and was predicted to be heavily O-glycosylated, similar to the primate DEFB126 (29, 32 and 75). Other epididymal secreted BDs like murine Defb-15 have also been predicted to be heavily 0glycosylated which has a long 20AA extension in the $C^{\prime}$ of its protein (42). Only two proteins identified in this study had a greater level of O-linked glycosylation than BuBD-129 viz. Keratin (G3NOV2) a common contaminant in MS studies and an uncharacterized protein (F1MQ37). Our results suggested that the glycocalyx barrier on the buffalo spermatozoa is greatly removed or re-organized post elevated salt or PI-PLC treatments, as indicated by the changes in MFI values. The cognate glycans for ABL, LEL and JAC viz. galactosyl $(\beta-1,3) \mathrm{N}$ acetylgalactosamine, [GICNAc] $1-3, \mathrm{~N}$-acetylglucosamine and Gal of galactosyl $(\beta-1,3) \mathrm{N}$-acetylgalactosamine, respectively appeared to be lost or re-organized in a way to become unavailable for lectin binding after these treatments. The recognition of negatively charged, terminally positioned, sialic acids by MAL-II on the buffalo sperm surface indicated their role as a protective coat that bestows the buffalo sperm with the ability to evade immune responses $(29,32$ and 42). Alternatively, they mask the testicular protein components e.g. the receptors 
that permit the sperm to recognize and bind the oocyte's zona pellucida making the sperm invisible to the FRT's immune-surveillance $(3,29$ and 76). The reduction in the MFI indicated either the removal of (glyco)proteins from the buffalo sperm-surface or a change in conformation of the available glycans impeding the recognition hence lectin binding on its surface. Nevertheless, this approach can't pinpoint individual sperm glycoprotein rather identifies general shifts in the surface sugars

The presence of the BuBD-129 and 126 on the buffalo sperm surface was validated by the immunocytochemistry which also established their spatial distribution patterns. The BuBD-129 spanned the entire buffalo spermatozoa similar to the primate DEFB-126 (44, 77 and 78). It is established that the coats of maturation antigens and their interacting partners like the BDs, usually acquired in the epididymis, often exhibit restriction in spatial distribution and tend to localize to specific micro-domains. Nevertheless, few of them such as BuBD-129and the primate DEFB-126 are adsorbed globally along all the regions of the spermatozoa (29 and 40). This hints at functional orthology between the buffalo BuBD-129 and primate DEFB-126, apart from other similarities like gene length, chromosome cluster, an extended amino-acid tail at C-terminus, a high potential of O- and N-glycosylation and the preferential expression in the distal segments of MRT (75). The presence of BuBD-129 along the complete length of the buffalo spermatozoa presumably masks the putative sperm-specific antigenic proteins from immune recognition by the immune cells in the FRT. The immune protection of buffalo spermatozoa can be envisioned as its primary function, possibly by establishing a barrier between the buffalo sperm and various immunologic milieus of the FRT $(3,29$ and 76). This is because of the virtual absence of immune response against BuBDs when the sperm-surface extracted proteins were injected in female Wistar rats (V Batra, $\mathrm{R}$ Kumar and TK Datta, Unpublished data). On the other hand, the spatial distribution of BuBD-126 and BBD-126 (51) differs from the DEFB-126 binding pattern observed in monkeys (79) or rodents (80). The BuBD-126 was found to localize to the post-acrosomal region and the tail rather than environing the whole sperm surface. These speciesspecific differences could be ascribed to the high variability in the distribution pattern of glycans and the differential sperm associated glycan topography(SpAGT) amongst various species (28).

The blocking of BuBD-129 drastically reduced the cleavage as well as the blastocyst formation rates during IVF. It is well established that the antibodies directed against the sperm-specific antigens are a major cause of immunological infertility since they perturb the normal fertilization process ( 3,50 and 81). How the anti-sperm antibodies target the sperm is not clearly understood. One facet of this obscurity may be unravelled by our demonstration that blocking the BuBD-129 precluded a successful fertilization event which confirmed their presence on buffalo sperm even after capacitation. Likewise, the ortholog of primate DEFB-126 in mice has been demonstrated to incorporate in the oolemma during gamete fusion which subsequently floated and extended out from the fused spermatozoa (90 and 91). Besides, its ortholog in cattle has been reported to be retained on the sperm surface, after induction of in vitro capacitation (51). This suggests that the BBD-126, like its ortholog defb22, remains associated with the spermatozoa during fertilization indicating an additional role in fertilization (80). The antibodies to heavily glycosylated BuBD-129 interfered with normal fertilization event apparently by inhibiting the recognition of oocytes by spermatozoa. It has been proposed that these features may be true for all the BDs with high levels of O-glycosylation (84). Similar to BuBD-129, antibodies against another member of the CAP superfamily, CRISP1 have been demonstrated to obstruct fertilization by interfering in the sperm-oocytes fusion process, thus reducing fertility. The cysteine-rich defensin-like peptides appear to be integral to the reproductive success of organism ranging from invertebrates, plants to higher primates $(85,86$ and 87$)$. It is equally likely that the blocking of BuBD-129 changes the attributes of sperm surface features which not only influence fertility but also the developmental potential of the subsequent embryos. The BuBD-129 probably 
imparts surface properties that are essential for fertilization by the buffalo sperm due to its glycocalyx and uniform distribution on entire buffalo sperm (88). These results suggest multiple and putatively epistatic roles of the $\mathrm{BD}$ genes in immune response and reproductive physiology of buffalo, e.g.in the process of sperm-oocytes interaction.

\section{Conclusion}

The buffalo sperm surface is heavily glycosylated and many glycoproteins are applied as peripheral coats on to the surface of mammalian spermatozoa. Many of these glycoproteins are immune-regulatory and have reproduction-specific functions. The molecular functions and biological roles of only a limited number of such proteins have been studied regarding their role in male reproductive physiology. The BuBDs like BuBD-129 and 126 are amongst the dominant molecules of the buffalo sperm surface. It would be interesting to quantify the BuBD-129 abundance in LF and HF bulls with contrasting field CRs through a targeted proteomics approach. The effect of exogenous supplementation of recombinant BuBD-129 to the low fertile sperm to augment the current field fertility rates should also be evaluated. Further investigations into the functional roles of this critical component of buffalo sperm are warranted.

\section{Methods}

\section{Chemicals and plasticware}

Chemicals and media used in the present study were obtained from Sigma Chemicals Co., St. Louis, Missouri, USA/ Qiagen/Fermentas/Invitrogen as mentioned for specific cases.

\section{Semen collection and pre-processing:}

Freshly ejaculated normozoospermic semen samples (mass motility $\geq 3, n=5-12$, aged between 3 and 5 years) were collected from mature Murrah buffalo bulls (of proven fertility) using the artificial vagina at the Artificial Breeding Research Centre (NDRI, Karnal, India). Each ejaculate was collected in a $15 \mathrm{~mL}$ centrifuge tube containing twice the volume of non-capacitating media (NCM), Sp-TALP i.e. HEPES buffered Tyrode's medium $\left(\mathrm{pH} 7.4,37^{\circ} \mathrm{C}\right)$. The semen was transported to the laboratory at $37^{\circ} \mathrm{C}$ and was washed thrice with Sp-TALP by centrifuging at $280 \mathrm{xg}$ for $6 \mathrm{~min}$ to remove the seminal plasma and its protein components. The motile spermatozoa were selected by subjecting the final pellet to swim-up technique. The upper $1.5 \mathrm{~mL}$ volume was later collected and centrifuged to obtain the pellet of motile spermatozoa.

\section{Surface protein extraction from motile spermatozoa}

\section{a) Elevated salt extraction of surface proteins:}

The post-swim-up spermatozoa in Sp-TALP were washed in DPBS and divided into four groups by re-suspending in either $2 X$ or $4 X$ DPBS for $30 \mathrm{~min}$ and $60 \mathrm{~min}$ at $37^{\circ} \mathrm{C}$ (viz. $2 \mathrm{X}-30,2 \mathrm{X}-60,4 \mathrm{X}-30$ and $4 \mathrm{X}-60$ ). The micro-centrifuge tubes were shaken gently during the period of incubation and the samples were subsequently pelletized by 
centrifugation at $280 \mathrm{xg}$ for $10 \mathrm{~min}$. A pool of supernatants from 5-7 ejaculates was collected and subsequently filtered through a $0.22 \mu \mathrm{m}$ filter. The proteins in the filtrate were precipitated with acetone precipitation method (1:9, supernatant/acetone ratio), concentrated on a speed-vac vacuum concentrator and subjected to SDS-PAGE after quantification by Quick Start ${ }^{\mathrm{TM}}$ Bradford protein assay.

\section{b) PI-PLC extraction of GPI-linked Proteins:}

The post-swim-up spermatozoa $\left(100 \times 10^{6}\right)$ in Sp-TALP were incubated with three different concentrations of Phosphoinositide-phospholipase C (PI-PLC) from Bacillus cereus $(1 \mathrm{U} / \mathrm{mL}, 1.5 \mathrm{U} / \mathrm{mL}$ and $2 \mathrm{U} / \mathrm{mL})$ in siliconized tubes at $37^{\circ} \mathrm{C}$ for $2 \mathrm{hrs}$. The siliconized tubes were shaken gently during the period of incubation. Thereafter, the samples were centrifuged at $1000 \mathrm{x}$ g for $10 \mathrm{~min}$ and the supernatants were collected and then filtered through a $0.22 \mu \mathrm{m}$ filter. The supernatants from 10-12 ejaculates were pooled and then precipitated by acetone precipitation method and quantified before subjecting to SDS-PAGE.

\section{Mass Spectrometry (LC-MS/MS) of sperm-surface extracted proteins}

For identification of sperm surface proteins mass-spectrometry was performed using the method described by Gourinath et al. (89). The extracted proteins $(100 \mu \mathrm{g})$ from the four elevated salt and three PI-PLC extractions were dissolved in $6 \mathrm{M}$ guanidium hydrochloride. Subsequently, $25 \mu \mathrm{L}$ of the dissolved samples were reduced with $5 \mathrm{mM}$ tris (2-carboxyethyl) phosphine (TCEP). The samples were then alkylated with 50mM iodoacetamide for $20 \mathrm{~min}$ in dark at room temperature (RT) and then digested with trypsin (1:50, trypsin/lysate ratio) for $16 \mathrm{~h}$ at $37^{\circ} \mathrm{C}$ after re-suspension in digestion buffer. The digests were cleaned using a C18 silica cartridge to remove the salt and dried using a speed vac vacuum concentrator. The dried pellet was resuspended in buffer A ( $5 \%$ acetonitrile, $0.1 \%$ formic acid). All the experiments were performed using EASY-nLC 1000 system (Thermo Fisher Scientific), which was coupled to a QExactive Mass Spectrometer (Thermo Fisher Scientific) equipped with nanoelectrospray ion source. $1 \mu \mathrm{g}$ of the peptide mixture was resolved using a $25 \mathrm{~cm}$ PicoFrit column (360 $\mu \mathrm{m}$ outer diameter, $75 \mu \mathrm{m}$ inner diameter, $10 \mu \mathrm{m}$ tip) filled with $1.8 \mu \mathrm{m}$ of C18-resin (Dr Maisch, Ammerbuch, Germany). The peptides were loaded with buffer $A$ and eluted with a $0-40 \%$ gradient of buffer B ( $95 \%$ acetonitrile, $0.1 \%$ formic acid) at a flow rate of $300 \mathrm{~nL} / \mathrm{min}$ for $90 \mathrm{~min}$. The MS data were acquired using a data-dependent top 10 method dynamically choosing the most abundant precursor ions from the survey scan (Fig. 5). All raw MS data have been deposited to the ProteomeXchange consortium through the PRIDE partner repository (Identifier:

PXD022114)

\section{Data processing}

The generated raw files for the seven samples were analyzed using Trans-Proteomic Pipeline TPP v5.1 (Syzygy) rev. 0 (90), against a database generated from UniProt knowledgebase (Bos taurus, Bubalus bubalis and betadefensin, downloaded January 3, 2019; www.uniprot.org) using the Comet search engine (91). The precursor and fragment mass tolerances were set at $10 \mathrm{ppm}$ and $0.5 \mathrm{Da}$, respectively. The enzyme specificity was set to trypsin/Panda maximum of two missed cleavages were allowed. Carbamidomethyl on cysteine (C) was considered as fixed modification while oxidation of methionine and $\mathrm{N}$-terminal acetylation were considered as 
variable modifications for the database search. The peptide spectrum match and protein false discovery rates (FDR) were set to 0.01 to increase the confidence and remove the false-positive identifications. Only the proteins with iProphet probability greater than 0.99 were considered for further analysis (92).

\section{Singular Enrichment and Scatter Plot analyses of the identified proteins}

The gene-ontology and singular enrichment analysis for identified proteins in all of the seven treatments were performed using agriGO (93) which is a specialized GO analysis toolkit and database for livestock species relevant to the agricultural community. For SEA (Singular Enrichment Analysis), the Bovine genome locus (Bovine Genome Database): GLEAN_03528 was used as background dataset and Fisher's test was used to calculate the p-values. The Yekutieli (FDR under dependency) method (94) was used for Multi-test adjustment. The minimum number of mapping entries for analysis was set to 5 and values with $p \leqslant 0.05$ were considered significant. The resulting long lists of Gene Ontology terms were summarized by REViGO webserver (95) which removes the redundant terms and the remaining terms were visualized in semantic similarity-based scatterplots. The SimRel was used as the semantic similarity measure (clustering algorithm) against whole Uniprot database which employs a multidimensional scaling procedure which initially places the terms using eigen value decomposition of the terms' pairwise distance matrix. This was followed by a stress minimization step which iteratively improves the agreement between the GO terms' semantic similarities and their closeness in the displayed twodimensional space.

\section{Flow cytometry}

The validation of the surface (glyco)protein removal after elevated salt and PI-PLC treatments was done by flow cytometry using six lectins viz. ABL, LEL, JAC, MAL-II, LCA and PNA, which bind to various cognate glycans on the sperm surface, including an unstained sample as the negative control $(n=3)$. A protocol for sperm flow cytometry analysis standardized by Batra et al. (28) was followed for signal acquisition. Briefly, the sperm were washed as described earlier and concentration was adjusted to $3 \times 10^{6} \mathrm{sperm} / \mathrm{ml}$. Samples were incubated with lectins for $10 \mathrm{~min}$ at $38.6^{\circ} \mathrm{C}$ under an atmosphere of $5 \% \mathrm{CO}_{2}$ before the flow cytometry analysis which was performed with a standard bench-top BD Accuri C6 flow cytometer (Becton Dickinson Biosciences, Ann Arbor, MI, USA, with BD Accuri $\mathrm{C} 6$ software v.1.0.27.1). The cytometer was calibrated daily according to the manufacturer's recommendations with 8 and 6 peak calibration beads and QC was performed every second day using BD CS\&T RUO beads. The 488-nm laser was used for the excitation of FITC, and its emission was filtered using a 533/30 bandpass filter. Filtered emissions were detected by photomultiplier tubes. A threshold of 80,000 in the forward scatter (FSC) signal was applied to remove electrical noise, and very small events and samples were acquired at a low flow rate $(14 \mu \mathrm{l} / \mathrm{min})$. For each sample, 20,000 events (single cells) were acquired. Only the singlet population was identified and used for analyses. The statistical analyses were performed on Prism Graphpad 7.0 (for Windows, GraphPad Software, La Jolla California USA, www.graphpad.com) by one way ANOVA to test the difference of means and the Brown-Forsythe test to test the differences in the standard deviations of the MFI values produced from various FITC-bound lectins. 


\section{Antibody development for determining the spatial distribution pattern of BuBD-129 and 126}

A custom polyclonal antibody specific for BuBD-129 and 126 was commercially generated by Genei using a standard protocol. Briefly, the amino acid peptide sequences from the secreted fragments of BuBD-129 and 126 were selected based on computational modelling on IEDB (96) for being surface epitopes. After chemical synthesis and conjugation to keyhole limpet hemocyanin (KLH), the epitope $(500 \mu \mathrm{g}$ mixed with Freund's complete adjuvant) was inoculated subcutaneously into the back of the neck region of sexually mature nulliparous female New Zealand white rabbits ( $n=1$, each group) weighing between 1.1-1.5Kg ( 1 animal per cage). The pre-immune sera (control) were extracted from the blood taken from the central ear vein by the skilled

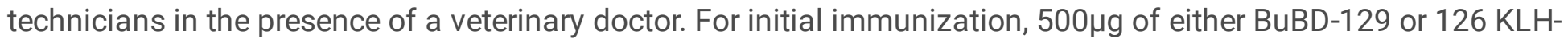
conjugated peptide was mixed in $500 \mu$ l of Freund's complete adjuvant and administered subcutaneous route in the back of the neck region of the animal. However, for booster doses $300 \mu \mathrm{g}$ of the antigen mixed in $500 \mu \mathrm{l}$ of Freund's incomplete adjuvant and administered similarly to initial immunization. An immune response was confirmed by binding of serum to the antigen on an enzyme-linked immunosorbent-type assay. The antibody titer was checked using western blot and seven booster doses were deemed necessary to obtain working IgGs isolated from the serum. The blood was collected by bleeding the rabbit through the central ear vein by trained individuals in the presence of a veterinary doctor. The whole blood $(5 \mathrm{ml})$ was subsequently collected from the central ear vein and allowed to clot at RT for 30min. The serum was isolated from the blood and Protein $\mathrm{G}$ based $\mathrm{NAb}^{\mathrm{TM}}$ Spin Kits were used for isolation of IgG antibodies from the collected serum according to the manufacturer's instructions. The subsequent quantification of BuBD-129 and $126 \mathrm{lgG}$ antibodies from the serum was performed by measuring the $A_{280}$ of each eluate fraction on an Infinite ${ }^{\circledR} 200$ NanoQuant microplate reader (Tecan). A confirmatory SDS-PAGE was performed to validate the isolated IgGs.

\section{Immunocytochemistry}

The swim-up fraction of spermatozoa $\left(40 \times 10^{6} \mathrm{cells} / \mathrm{ml}\right)$ was re-suspended in NCM and was added onto poly-Llysine coated slides. The NCM was removed after $15 \mathrm{~min}$ since the spermatozoa adhered to the slide surface by that time. Subsequently, the cells were washed twice in PBS and fixed in $2 \%$ paraformaldehyde and $0.1 \%$ glutaraldehyde for 20 min at RT. The movement of the GPI-linked proteins is prevented by using low glutaraldehyde concentration. The spermatozoa were then washed with PBS thrice, and the slide surface was then blocked with blocking buffer (1\% BSA in PBST-0.1\% Tween 20 in 1X-PBS) for 1 hour at room temperature. The cells were later incubated with the primary polyclonal antibody (1:1000 dilutions) against BuBD-129 and 126 overnight at $4^{\circ} \mathrm{C}$. The sperm were washed with PBST thrice and were then incubated with FITC conjugated goat anti-rabbit IgG secondary antibody (1:5000 dilutions; Sigma-Aldrich) in dark for 1 hour at RT followed by final washings with PBST (3x). After the final washing, a coverslip was mounted onto a glass slide onto which one drop of mounting medium, Dabcoß $33-$ LV was placed. The cells were then observed under a BX-51 Olympus fluorescence microscope. The loss of the BuBD-129 and 126 from the sperm-surface after incubation of spermatozoa in 2X-DPBS or exposing them to $2 \mathrm{U} / \mathrm{ml}$ of PI-PLC was similarly monitored by immunocytochemistry (ICC) after the stipulated times of incubation.

\section{IVF study}


The IVF was performed using the procedure described by Verma et al. (97) in the control and three treatment groups. The control group was without anti-BuBD-129 and the three treatment groups comprised of three different concentrations of anti-BuBD-129 $(0.5 \mathrm{mg} / \mathrm{ml})$ antibody in the fertilization medium drops viz. the 1:15000, 1:10000 and 1:5000 dilution groups. A total of four biological replicates were used for the IVF experiments. The data were analyzed on GraphPad prism7 (for Windows, GraphPad Software, La Jolla California USA, www.graphpad.com) to compare the observed differences in cleavage and blastocyst rates among the control and treatment groups.

\section{Abbreviations}

ABL -Agaricus bisporus lectin, AMPs- Antimicrobial peptides, BD/ DEFB - Beta-defensin, BuBD- Buffalo betadefensin, CA-BD-Class-A beta-defensin, CMP-Cervical mucus penetration, CR-Conception rate, GPIGlycosylphosphatidylinositol, FRT- Female reproductive tract, ICC- immunocytochemistry, IFImmunofluorescence, JAC - Jacalin, LCA-Lens culinaris agglutinin, LC-MS/MS- Liquid chromatography, tandem mass spectrometry, LEL- Lycopericon esculentum lectin, MAL II- Maackia amurensis lectin, MRT- Male reproductive tract, OEC - Oviductal epithelial cells, PI-PLC-Phosphoinositide-phospholipase C, PNA-Peanut agglutinin, SEA-Singular enrichment analysis, SPA-Scatter Plot analysis, SSR- Sperm surface remodelling,

\section{Declarations}

\section{- Ethics approval and consent to participate:}

The animal study was reviewed and approved by Institutional Animal Ethics Committee (IAEC), National Dairy Research Institute (NDRI). All experiments were performed in accordance with guidelines and regulations laid by IAEC-NDRI. The study was carried out in compliance with the ARRIVE guidelines.

\section{- Consent for publication:}

Not Applicable

\section{- Availability of data and material:}

All data generated or analysed during this study are included in this published article and its supplementary information files. The LC-MS/MS data are available via ProteomeXchange with identifier PXD022114. The flow cytometry datasets generated from this study can be found in the FlowRepository (Rep ID: FR-FCM-Z3BX).

\section{- Competing interests:}

The authors declare that they have no competing interests

\section{- Funding:}

This work was supported by the Bill \& Melinda Gates Foundation [grant number OPP1154401].

\section{- Authors' contributions:}


Study was designed by VB ${ }^{1}, \mathrm{RK}$ and TKD. Analysis of proteomics data was done by VB ${ }^{1}, V^{2} 2$ and SAA. The IVF was performed by PS. The images were generated by AK and SS. The manuscript was written by VB ${ }^{1}$. All the authors read and approved the final manuscript

\section{- Acknowledgement:}

The critical inputs of Dr Suneel Onteru, Sr. Scientist, Animal Biochemistry, NDRI in the final version of the manuscript are gratefully acknowledged.

\section{References}

1. Ikawa M, Inoue N, Benham AM, Okabe M. Fertilization: A sperm's journey to and interaction with the oocyte. J Clin Invest. 2013; 120:984-994.

2. Bianchi E, Wright GJ. Sperm meets egg: The genetics of mammalian fertilization Ann Rev Genet. 2016; 50:93-111.

3. Archana SS, Selvaraju S, Binsila BK, Arangasamy A, Krawetz SA. Immune regulatory molecules as modifiers of semen and fertility: A review Mol Reprod Dev. 2019; 86:1485-1504.

4. Voisin A, Saez F, Drevet JR, Guiton R. The epididymal immune balance: A key to preserving male fertility. Asian J Androl. 2019; 21:1-9.

5. Katila T. Post-mating inflammatory responses of the uterus. Reprod Dom Animals. 2012; 47: 31-41.

6. Hall JC, Killian GJ. Changes in rat sperm membrane glycosidase activities and carbohydrate and protein contents associated with epididymal transit. Biol Reprod. 1987; 36:709-718.

7. Sullivan R, Mieusset R. The human epididymis: its function in sperm maturation. Hum Reprod Update. 2016; 22: 574-587.

8. Jones R, Brown CR. Identification and characterization of the $2 \mathrm{D} 6$ and Mr 23000 antigens on the plasma membrane of rat spermatozoa. Biochem J. 1987; 241:353-360.

9. Guyonnet B, Dacheux F, Dacheux JL, Gatti JL. The epididymal transcriptome and proteome provide some insights into new epididymal regulations. J Androl. 2011; 32: 651-664.

10. Belleannée C, Labas V, Teixeira-Gomes AP, Gatti JL, Dacheux JL, Dacheux F. Identification of luminal and secreted proteins in bull epididymis. J Proteomics. 2011a; 74:59-78.

11. Belleannée C, Belghazi M, Labas V, Teixeira-Gomes AP, Gatti JL, Dacheux JL, Dacheux F. 2011(b) Purification and identification of sperm surface proteins and changes during epididymal maturation. Proteomics. 2011b; 11:1952-64.

12. Ribeiro CM, Silva Erick JR, Hinton BT, Avellar MCW. $\beta$-defensins and the epididymis: contrasting influences of prenatal, postnatal, and adult scenarios. Asian J Androl. 2016; 18:323-328.

13. Skerget S, Rosenow MA, Petritis K, Karr TL. Sperm proteome maturation in the mouse epididymis. PLoS One. 2015; 10(11):e0140650.

14. Aitken RJ, Nixon B, Lin M, Koppers AJ, Lee YH, et al. Proteomic changes in mammalian spermatozoa during epididymal maturation. Asian J Androl. 2007; 9:554-564.

15. Diekman, A. Glyco-conjugates in sperm function and gamete interactions: How much sugar does it take to sweet-talk the egg? Cell Mol Life Sci. 2003; 60:298-308. 
16. Robaire B, Hinton BT. The epididymis. In: Plant TM, Zeleznik AJ, editors. Knobil and Neill's Physiology of Reproduction. $4^{\text {th }}$ San Diego: Academic Press; 2015. p. 691-771.

17. Tulsiani DR. Glycan-modifying enzymes in luminal fluid of the mammalian epididymis: An overview of their potential role in sperm maturation Mol Cell Endocrinol. 2006; 250:58-65

18. Cooper TG, Yeung CH. Sperm maturation in the human epididymis. In: De Jonge C, Barratt C, editors. The Sperm cell production, maturation, fertilization, regeneration. Cambridge: Cambridge University Press; 2006. p. $72-107$.

19. Tecle E, Gagneux P. Sugar-coated sperm: Unraveling the functions of the mammalian sperm glycocalyx. Mol Reprod Dev. 2015; 82:635-50.

20. Métayer S, Dacheux F, Dacheux JL, Gatti JL. Comparison, characterization and identification of protease and protease inhibitors in epididymal fluid of domestic mammals. Matrix metalloproteinases are major fluid gelatinases. Biol Reprod. 2002; 66:1219-1229.

21. Wu YC, Xin AJ, Lu H, Diao H, Cheng L, et al. Effects of cryopreservation on human sperm glycocalyx. Rep Dev Med. 2017; 1:233-238.

22. Zhou W, Stanger SJ, Anderson AL, Bernstein IR, De luliis GN, et al. Mechanisms of tethering and cargo transfer during epididymosome-sperm interactions. BMC Biol. 2019; 17:35.

23. Martin-DeLeon PA. Epididymosomes: Transfer of fertility-modulating proteins to the sperm surface. Asian $\mathrm{J}$ Androl. 2015; 17:720-5.

24. Frenette G, Girouard J, D'Amours O, Allard N, Tessier L, Sullivan R. Characterization of two distinct populations of epididymosomes collected in the intraluminal compartment of the bovine cauda epididymis. Biol Reprod. 2010; 83: 473-480.

25. Légaré C, Akintayo A, Blondin P, Calvo E, Sullivan R. Impact of male fertility status on the transcriptome of the bovine epididymis. Mol Hum Reprod. 2017; 23, 355-369.

26. Kirchoff C. Molecular characterization of epididymal proteins. Rev Reprod. 1998; 3:86-95.

27. Holland MK, Nixon B. The specificity of epididymal secretory proteins. J Reprod Fertil. 1998; 53:197-210.

28. Batra V, Dagar K, Nayak S, Kumaresan A, Kumar R, Datta TK. A higher abundance of O-linked glycans confers a selective advantage to high fertile buffalo spermatozoa for immune-evasion from neutrophils. Front Immunol. 2020; 11:1928.

29. Tollner TL, Bevins CL, Cherr GN. Multi-functional glycoprotein DEFB126- A curious story of defensin-clad spermatozoa. Nat Rev Urol. 2012; 9:365-375.

30. Lyons A, Narciandi F, Donnellan E, Romero-Aguirregomezcorta J, O’Farrelly C, Lonergan P, et al. Recombinant $\beta$-defensin 126 promotes bull sperm binding to bovine oviductal epithelia. Reprod Fert Dev. 2018; 30:147281.

31. Pang PC, Chiu PCN, Lee CL, Chang LY, Panico M, Morris HR et al. Human sperm binding is mediated by the sialyl-Lewis(x) oligosaccharide on the zona pellucida. Science 2011; 333: 1761-1764.

32. Tollner TL, Venners SA, Hollox EJ, Yudin Al, Liu X, et al. A common mutation in the defensin DEFB126 causes impaired sperm function and subfertility. Sci Transl Med. 2011; 3:92ra65.

33. Scherf BD. World watch list for domestic animal diversity. Food and Agriculture Organization of the United Nations, Rome. Third edition; 2000. 
34. Khatun M, Kaur S, Kanchan, Mukhopadhyay CS. Subfertility problems leading to disposal of breeding bulls.Asian-Australas. J Anim Sci. 2013; 26:303-308.

35. Mukhopadhyay CS, Gupta AK, Yadav BR, Gupta A, Mohanty TK, Raina VS. Study on the effect of various uncompromisable traits on fertilizing potential in cattle and buffalo bulls. Livest Sci. 2011; 136:114-121.

36. Annual report 2017-18 and project coordinator's observations: Network project on buffalo improvement. 2018. https://cirb.res.in/annual-reports.

37. Berry DP, Evans RD, Mc Parland S. Evaluation of bull fertility in dairy and beef cattle using cow field data. Theriogenology 2011; 75: 172-181.

38. Parkinson TJ. Evaluation of fertility and infertility in natural service bulls. Vet J. 2004; 168, 215-229.

39. Xin A, Cheng LM, Diao H, Wu Y, Zhou S, Shi C, et al. Lectin binding of human sperm associates with DEFB126 mutation and serves as a potential biomarker for subfertility. Sci Rep. 2016; 6:20249.

40. Yanagimachi R. Mammalian fertilization. In: Knobil E, Neill JD, editors. The physiology of reproduction.Vol.1, Raven Press:New York; 1994. p. 189-317.

41. Suarez SS. Mammalian sperm interactions with the female reproductive tract. Cell Tissue Res. 2016; 363:185-194.

42. Zhou CX, Zhang YL, Xiao L, Zheng M, Leung KM, Chan MY, et al. An epididymis-specific beta-defensin is important for the initiation of sperm maturation. Nat Cell Biol. 2004; 6:458-464.

43. Zhao Y, Diao H, Ni Z, Hu S, Yu H, Zhang Y. The epididymis specific antimicrobial peptide $\beta$-defensin 15 is required for sperm motility and male fertility in the rat (Rattus norvegicus). Cell Mol Life Sci. 2011; 68:697708.

44. Yudin Al, Tollner TL, Li MW, Treece CA, Overstreet JW, Cherr GN. ESP13.2, a member of the beta-defensin family, is a macaque sperm surface-coating protein involved in the capacitation process. Biol Reprod. 2003; 69:1118-1128.

45. Aram R, Chan PTK, Cyr DG. Beta-defensin126 is correlated with sperm motility in fertile and infertile men. Biol Reprod. 2020; 102:92-101.

46. Zhang J, Ahn J, Suh Y, Hwang S, Davis ME, Lee K. Identification of CTLA2A, DEFB29, WFDC15B, SERPINA1F and MUP19 as novel tissue-specific secretory factors in mouse. PloS One. 2015; doi; 10.1371/journal.pone.0124962.

47. Cooper TG. The epididymis, sperm maturation and fertilization. Springer Science \& Business Media; 2012.

48. Cornwall GA. Role of posttranslational protein modifications in epididymal sperm maturation and extracellular quality control. In: Sutovsky P. editor. Post-translational protein modifications in the reproductive system. Springer New York; 2014. p. 159-180

49. Gwathmey TM, Ignotz GG, Mueller JL, Manjunath P, Suarez SS. Bovine seminal plasma proteins PDC-109, BSP-A3, and BSP-30-kDa share functional roles in storing sperm in the oviduct. Biol Reprod. 2006; 75:501507.

50. Yudin Al, Generao SE, Tollner TL, Treece CA, Overstreet JW, Cherr GN. $\beta$-defensin 126 on the cell surface protects sperm from immunorecognition and binding of anti-sperm antibodies. Biol Reprod. 2005b; 73:1243-1252.

51. Fernandez-Fuertes B, Narciandi F, O'Farrelly C, Kelly AK, Fair S, Meade KG, et al. Cauda epididymis-specific beta-defensin 126 promotes sperm motility but not fertilizing ability in cattle. Biol Reprod. 2016; 95(6): 122. 
52. Holt WV, Fazeli A. Do sperm possess a molecular passport? Mechanistic insights into sperm selection in the female reproductive tract. Mol Hum Rep. 2015; 21:491-501.

53. Holt WV. Surface-bound sialic acid on ram and bull spermatozoa: Deposition during epididymal transit and stability during washing. Biol Reprod. 1980; 23:847-857.

54. Defaus S, Avilés M, Andreu D, Gutiérrez-Gallego R. Identification of bovine sperm surface proteins involved in carbohydrate-mediated fertilization interactions. Mol Cell Prot. 2016; 5:2236-2251.

55. Schröter S, Osterhoff C, McArdle W, Ivell R. The glycocalyx of the sperm surface. Hum Reprod. 1999; 5:302313.

56. Légaré C, Sullivan R. Differential gene expression profiles of human efferent ducts and proximal epididymis. Andrology. 2019; 8:625-636

57. Légaré C, Akintayo A, Blondin P, Calvo E, Sullivan R. Impact of male fertility status on the transcriptome of the bovine epididymis. Mol Hum Reprod. 2017; 23, 355-369.

58. Girouard J, Frenette G, Sullivan R. Comparative proteome and lipid profiles of bovine epididymosomes collected in the intraluminal compartment of the caput and cauda epididymidis. Int J Androl. 2011; 34:e475e486.

59. Semple F, MacPherson H, Webb S, Kilanowski F, Lettice L, McGlasson SL, et al. Human $\beta$-D-3 exacerbates MDA5 but suppresses TLR3 responses to the viral molecular pattern mimic polyinosinic: polycytidylic acid. PLoS Genet. 2015; 11; e1005673

60. Sørensen OE, Borregaard N, Cole AM. Antimicrobial peptides in innate immune responses. Contrib Microbiol. 2008; 15:61-77.

61. Dean MD, Good JM, Nachman MW. Adaptive evolution of proteins secreted during sperm maturation: An analysis of the mouse epididymal transcriptome. Mol Biol Evol. 2008; 25:383-92.

62. Ribeiro CM, Romano RM, Avellar MCW. Beta-defensins in the epididymis: Clues to multifunctional roles. Animal Reprod. 2012; 9:9.

63. Dube E, Hermo L, Chan PT, Cyr DG. Alterations in gene expression in the caput epididymides of nonobstructive azoospermic men. Biol Reprod. 2008; 78:342-51.

64. Meade KG and and O'Farrelly C. $\beta$-Defensins: Farming the microbiome for homeostasis and health. Front Immunol. 2018; 9:3072.

65. Meade KG, Cormican P, Narciandi F, Lloyd A, O’Farrelly C. Bovine defensin gene family: Opportunities to improve animal health. Physiol Genomics. 2014; 46:17-28.

66. Dorin JR, McHugh BJ, Cox SL, Davidson DJ. Mammalian antimicrobial peptides; defensins and cathelicidins. In: Tang YW, Sussman M, Liu D, Poxton I, Schwartzman J, Molecular Medical Microbiology. Academic Press; 2015. p. 539-565.

67. Narciandi F, Fernandez-Fuertes B, Khairulzaman I, Jahns H, King D, Finlay EK, et al. Sperm-coating betadefensin 126 is a dissociation-resistant dimer produced by epididymal epithelium in the bovine reproductive tract. Biol Reprod. 2016; 95:121

68. Whiston R, Finlay EK, McCabe MS, Cormican P, Flynn P, Cromie A, et al. A dual targeted beta-defensin and exome sequencing approach to identify validate and functionally characterise genes associated with bull fertility. Sci Rep. 2017; 7:12287. 
69. Lyons A, Narciandi F, Donnellan E, Romero-Aguirregomezcorta J, O’Farrelly C, Lonergan P et al. Recombinant $\beta$-defensin 126 promotes bull sperm binding to bovine oviductal epithelia. Reprod Fert Dev. 2018; 30:147281

70. Fruitwala S, El-Naccache DW and Chang TL. Multifaceted immune functions of human defensins and underlying mechanisms. Semin Cell Dev Biol. 2019; 88:163-172.

71. Chapman JR, Hellgren O, Helin AS, Kraus RH, Cromie RL, Waldenström J. The evolution of innate immune genes: purifying and balancing selection on $\beta$-defensins in waterfowl. Mol Biol Evol. 2016; 33:3075-308.

72. Meade KG, Higgs R, Lloyd AT, Giles S, O'Farrelly C. Differential antimicrobial peptide gene expression patterns during early chicken embryological development. Dev Comp Immunol. 2009; 33:516-524.

73. Hall SH, Yenugu S, Radhakrishnan Y, Avellar MC, Petrusz P, French FS. Characterization and functions of beta defensins in the epididymis. Asian J Androl. 2007; 9:453-62.

74. Diao R, Fok KL, Chen H, Yu MK, Duan Y, Chung CM, et al. Deficient human $\beta$-defensin 1 underlies male infertility associated with poor sperm motility and genital tract infection. Sci Transl Med. 2014; 6:249ra108.

75. Batra V, Maheshwarappa A, Dagar K, Kumar S, Soni A, Kumaresan A, et al. Unusual interplay of contrasting selective pressures on $\beta$-defensin genes implicated in male fertility of the Buffalo (Bubalus bubalis). BMC Evol Biol. 2019; 19:214.

76. Fernandez-Fuertes B, Blanco-Fernandez A, Reid CJ, Meade KG, Fair S, Lonergan P. Removal of sialic acid from bull sperm decreases motility and mucus penetration ability but increases zonapellucida binding and polyspermic penetration in vitro. Reproduction. 2018; 155:481-492.

77. Duan S, Shi C, Chen G, Zheng JF, Wu B, Diao H, et al. Another functional frame-shift polymorphism of DEFB126 (rs11467497) associated with male infertility. J Cell Mol Med. 2015; 19:1077-84.

78. Yudin Al, Treece CA, Tollner TL, Overstreet JW, Cherr GN. The carbohydrate structure of DEFB126, the major component of the cynomolgus macaque sperm plasma membrane glycocalyx. J Memb Biol. 2005a; 207:119-1290

79. Tollner TL, Yudin Al, Treece CA, Overstreet JW, Cherr GN. Macaque sperm release ESP13.2 and PSP94 during capacitation: the absence of ESP13.2 is linked to sperm-zona recognition and binding. Mol Reprod Dev. 2004; 69:325-37

80. Yudin Al, Tollner TL, Treece CA, Kays R, Cherr GN, Overstreet JW, et al. Beta-defensin 22 is a major component of the mouse sperm glycocalyx. Reproduction. 2008; 136:753-65.

81. Bohring C, Krause E, Habermann B, Krause W. Isolation and identification of sperm membrane antigens recognized by anti-sperm antibodies, and their possible role in immunological infertility disease. Mol Hum Reprod. 2001; 7:113-118.

82. Brown $\mathrm{CR}$, von Glos $\mathrm{KI}$, Jones R. Changes in plasma membrane glycoproteins of rat spermatozoa during maturation in the epididymis. J Cell Biol. 1983; 96:256-264.

83. Hataska H. Immunologic factors in infertility. Clin Obstet Gynecol. 2000; 43:830-843.

84. Dorin JR, Barratt CL. Importance of $\beta$-defensins in sperm function. Mol Hum. Reprod 2014; 20(9):821-6.

85. Avila FW, Sirot LK, LaFlamme BA, Rubinstein CD, Wolfner MF. Insect seminal fluid proteins: identification and function. Ann Rev Entomol. 2011; 56:21-40.

86. Okuda S, Tsutsui H, Shiina K, Sprunck S, Takeuchi H, Ryoko Y, et al. Defensin-like polypeptide LUREs are pollen tube attractants secreted from synergid cells. Nature. 2009; 458:357-361.

Page 22/ 27 
87. Amien S, Kliwer I, Márton ML, Debener T, Geiger D, Dirk B, et al. Defensin-like ZmES4 mediates pollen tube burst in maize via opening of the potassium channel KZM1. PLoS Biol. 2010; 8:e1000388.

88. Takeuchi H, Higashiyama T. A species-specific cluster of defensin-like genes encodes diffusible pollen tube attractants in Arabidopsis. PLoS Biol. 2012; 10: e1001449.

89. Gourinath, S. Mass spectrometric analysis data of Pyruvate Kinase from E. histolytica. Mendeley Data, V1. 2019. http://dx.doi.org/10.17632/d9cvddpp53.1

90. Deutsch EW, Mendoza L, Shteynberg D, Slagel J, Sun Z, Moritz RL. Trans-Proteomic Pipeline, a standardized data processing pipeline for large-scale reproducible proteomics informatics. Proteomics Clin Appl. 2015; 9:745-54.

91. Eng JK, Jahan TA, Hoopmann MR. Comet: an open-source MS/MS sequence database search tool. Proteomics. 2013; 13:22-4.

92. Shteynberg D, Deutsch EW, Lam H, Eng JK, Sun Z, Tasman N, et al. iProphet: Multi-level integrative analysis of shotgun proteomic data improves peptide and protein identification rates and error estimates. Mol Cell Prot. 2011; 10(12):M111.007690.

93. http://bioinfo.cau.edu.cn/agriGO/. Accesses Nov20, 2019.

94. Yekutieli D and Benjamini Y. Resampling based False Discovery Rate controlling procedure for dependent test statistics. J Statist PIng Inf. 1999; 82(1-2):171-19.

95. Supek F, Bošnjak M, Škunca N and Šmuc T. REVIGO summarizes and visualizes long lists of Gene Ontology terms. PLoS one. 2011; doi:10.1371/journal.pone.0021800.

96. Fleri W, Paul S, Dhanda SK, Mahajan S, Xu X, Peters B, et al. The immune epitope database and analysis resource in epitope discovery and synthetic vaccine design. Front Immunol. 2017; 8:278.

97. Verma A, Kumar P, Rajput S, Roy B, De S, Datta TK. Embryonic genome activation events in buffalo (Bubalus bubalis) preimplantation embryos. Mol Rep Dev. 2012; 79(5) 321-8.

\section{Figures}

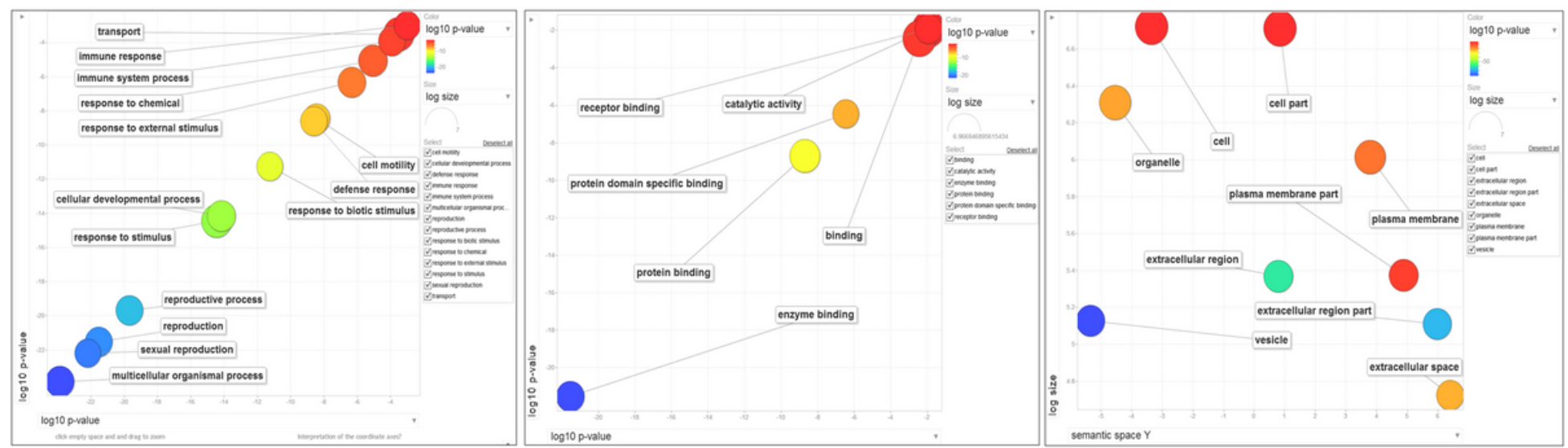

\section{Figure 1}

The scatter plot analysis (SPA) results for Biological Process, Molecular Function and Cellular Component GO terms of buffalo sperm surface proteins 
ABL
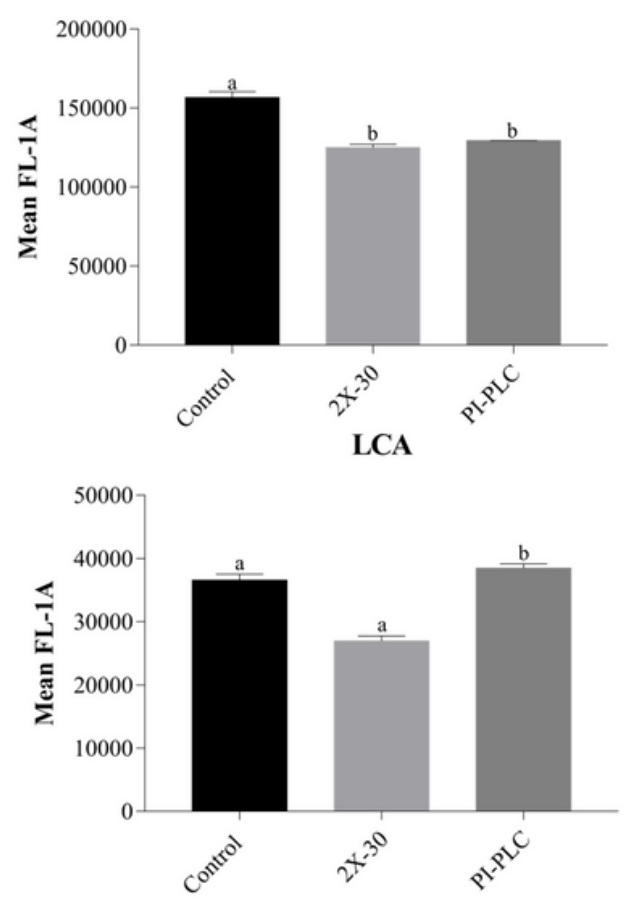

JAC
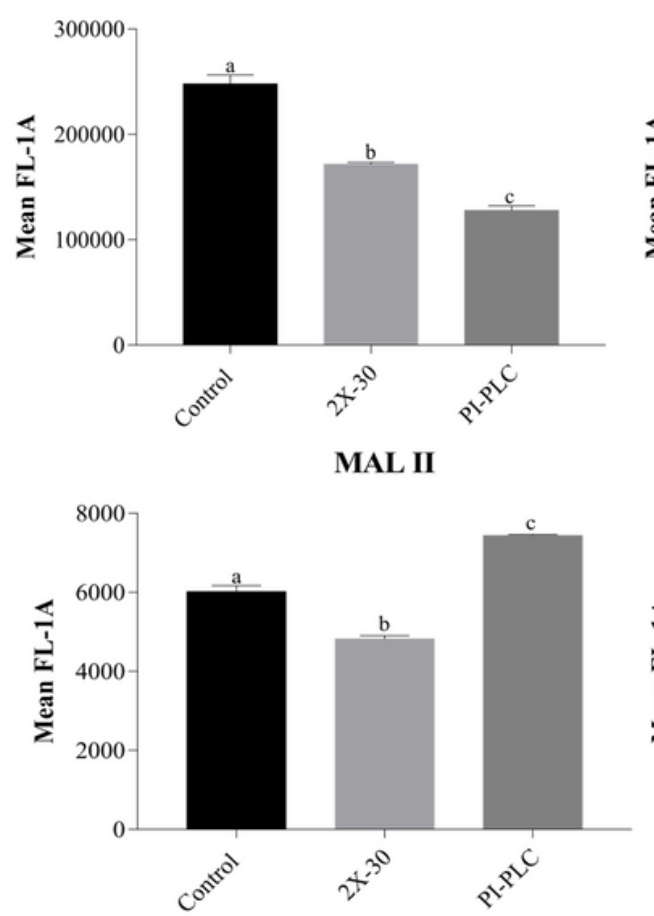

LEL
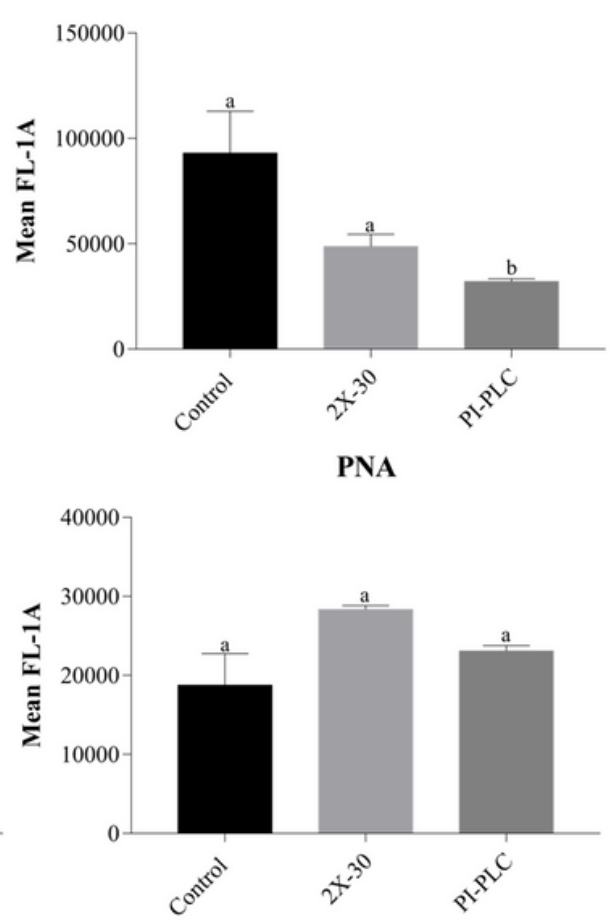

\section{Figure 2}

Histograms plots of the observed mean fluorescent intensities (MFIs) produced by binding of different lectins viz. ABL, JAC, LEL, LCA, MAL-II, and PNA on buffalo bull spermatozoa in NCM (control), 2X-DPBS (2X-30) or spermatozoa exposed to $2 \mathrm{U} / \mathrm{mL}$ PI-PLC. The differences being assessed by one way ANOVA followed by the Tukey's multiple comparison test. 


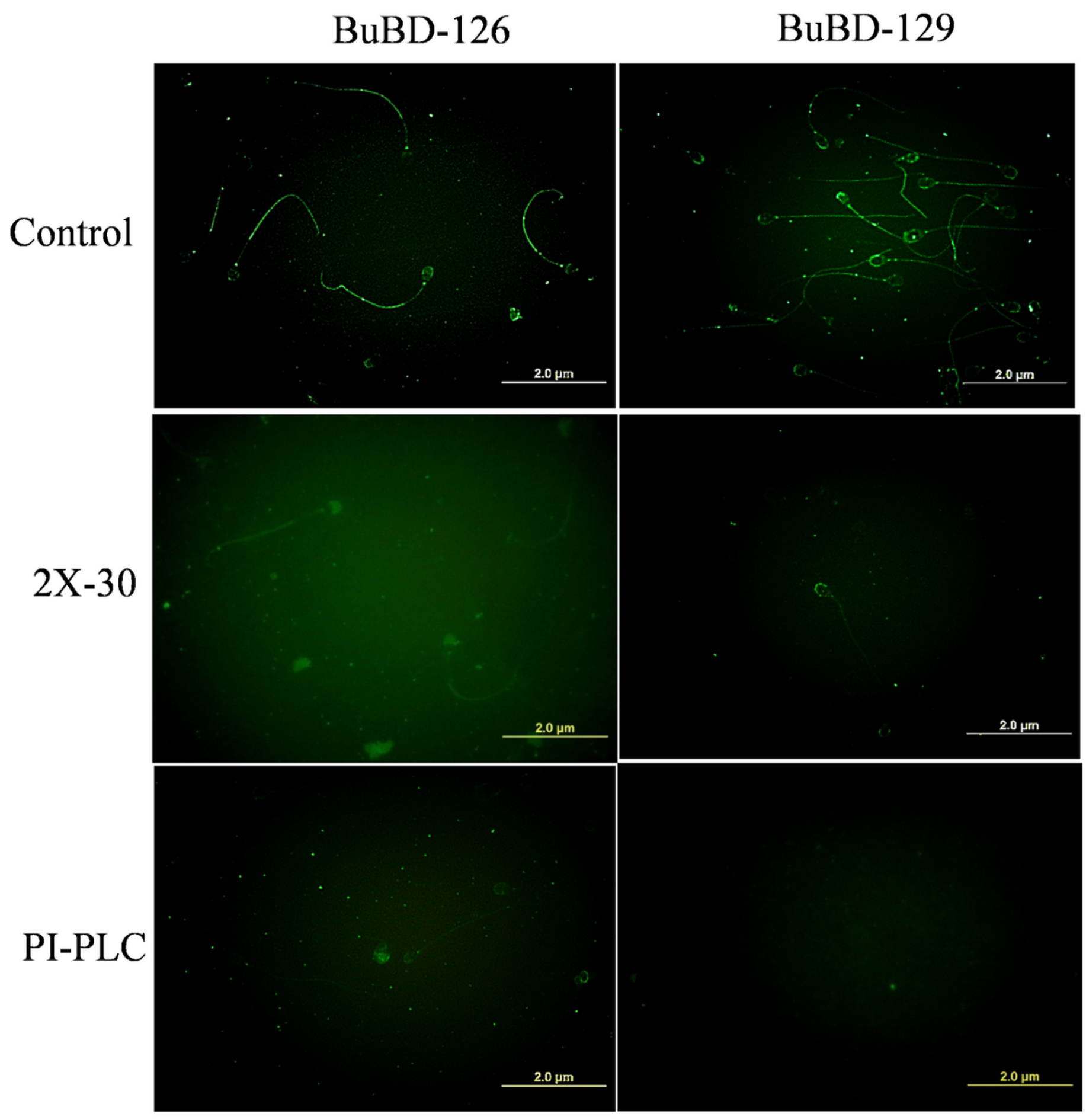

Figure 3

Immuno-localization pattern of the two CA-BDs viz. BuBD-126 and 129 using the in house generated anti-BuBD129 and 126 antibodies, respectively in rabbit against selected B-epitopes. The decrease of the fluorescent signal intensity pertaining to the removal of the CA-BDs, BuBD-126 and 129 from the buffalo bull sperm surface is observable after the 2X-DPBS and PI-PLC treatments. 
Cleavage rate

Morula formation rate

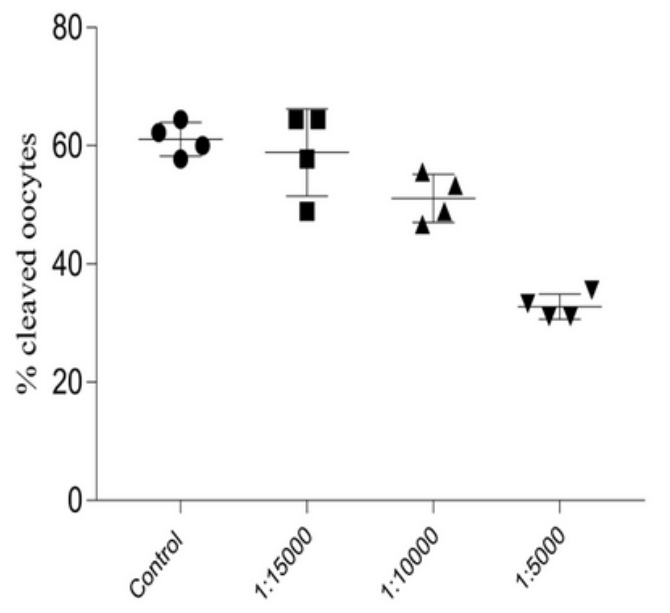

Dilution anti-BuBD-129

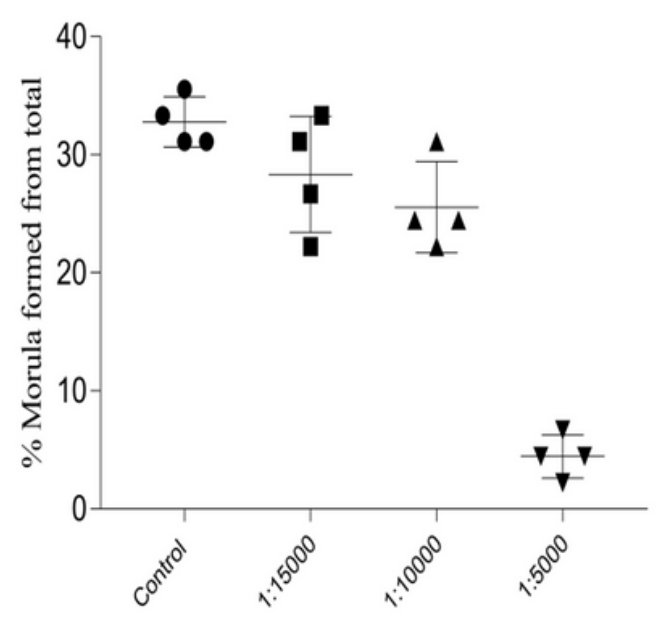

Dilution anti-BuBD-129
Blastocyst formation rate

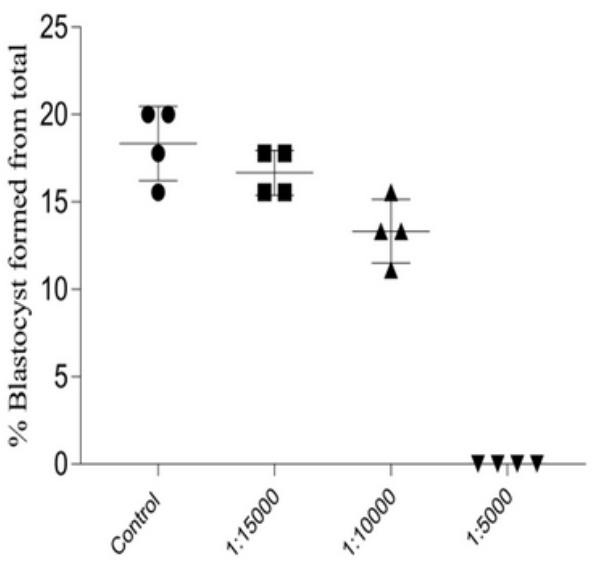

Dilution anti-BuBD-129

Figure 4

Scatter plots showing the mean \pm sd for cleavage, morula and blastocyst formation rates in the control group and samples treated with three different concentrations of anti-BuBD-129
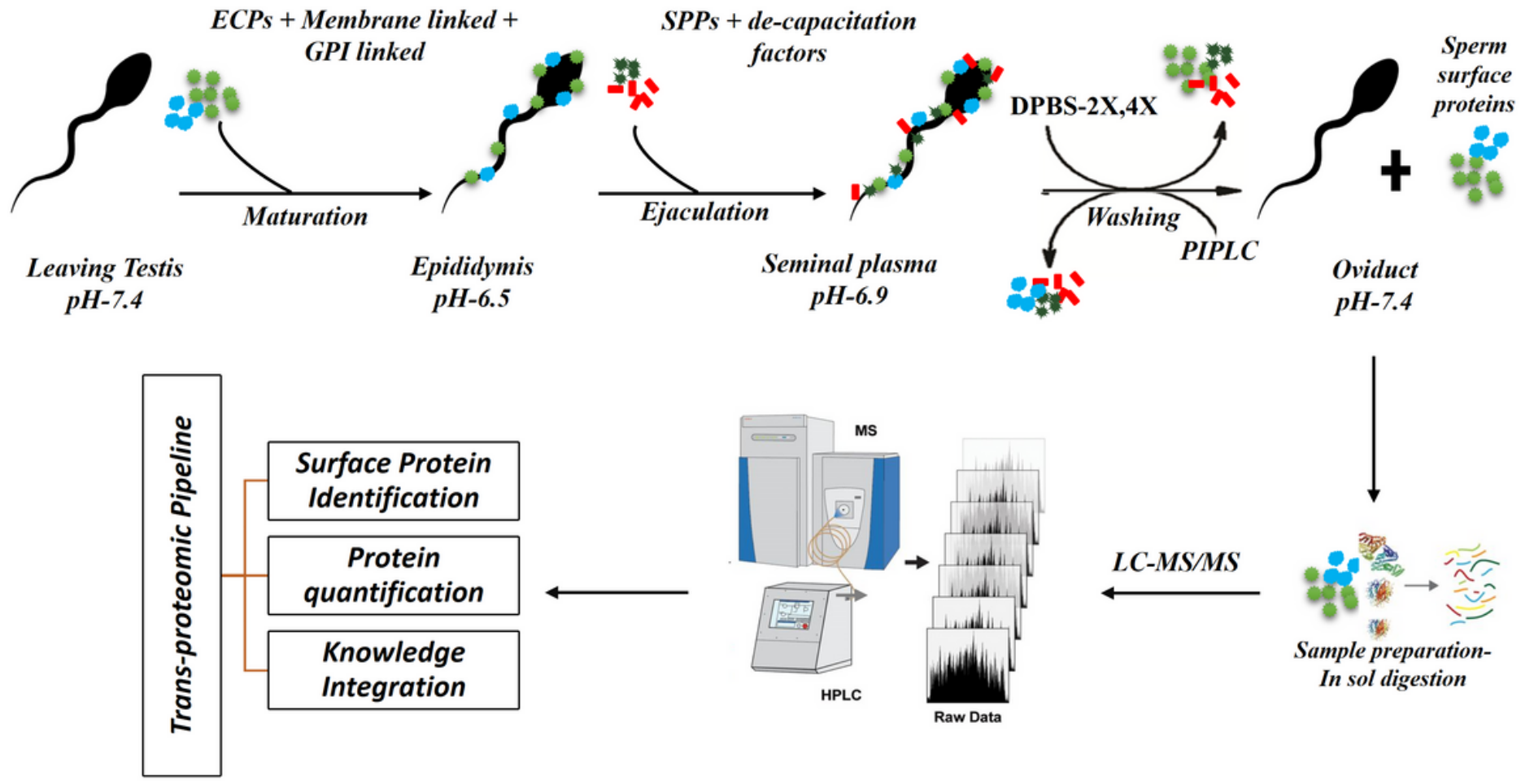

$L C-M S / M S$

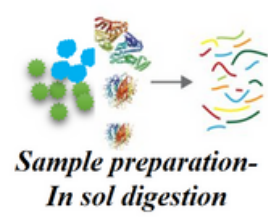

Figure 5

The overall research methodology followed for BuBD identification on the buffalo sperm surface by LC-MS/MS.

\section{Supplementary Files}

This is a list of supplementary files associated with this preprint. Click to download. 
- SupplementaryFig.1.tif

- SupplementaryFig.2.tif

- SupplementaryFig.3.png

- SupplementaryFig.4.tif

- SupplementaryFig.5.tif

- SupplementarysheetResults.xlsx 